\title{
TRANSFORMATIONAL LEADERSHIP AND EMPLOYEES' WORK EFFICIENCY: A PRIVATE FIRM CASE STUDY
}

\author{
Tikhamporn Punluekdej
}

\author{
Southeast Asia University, Bangkok, Thailand
}

The study has sought to investigate the effect of leadership styles practiced in an organization on employee performance. More specifically, this research is aimed to study: 1) the existing level of transformational leadership and work efficiency of employees at a private company, 2) employees' work efficiency based on individual factors, and 3) the relationship between transformation leadership and employees' work efficiency at a private company. The sample size includes 104 employees of a private company. The questionnaires have been distributed to collect the data. The statistical data used for the analysis includes percentage, mean, standard deviation, and Pearson's product moment correlation coefficient. The results reveal that: 1) the majority of the respondents are male, aged between 31-40 years old, holding a bachelor degree, and having work experience between 4 and 6 years; 2) the level of transformational leadership of employees is quite high. When considered separately by dimensions, it has been found that inspirational motivation and idealized influence are also at high level while intellectual stimulation and individualized consideration are at the moderate level; 3) the overall work effectiveness of employees has high level, 4) the individual variables of age, education, work experience and position have no relationship with work efficiency; and 5) there is a relationship between transformational leadership and employees' work efficiency at the level of significance being 0.01.

Keywords: transformational leadership; work efficiency; leadership style

\section{Introduction}

Changes in economic, social, cultural, political, and technological factors have delivered great direct and indirect impacts on business operations, especially in Thailand as the country is trying their best to develop and move forward, towards the Thailand 4.0 goals. In order to compete and survive in a highly competitive environment, every organization must adapt and adjust itself to suit the situation. Firms must consider both positive and negative factors that can be useful for formulation of guidelines or strategy for administration and sustainable development of organizations. There must also be a harmony and continuity of organizational directions at both domestic and international markets.

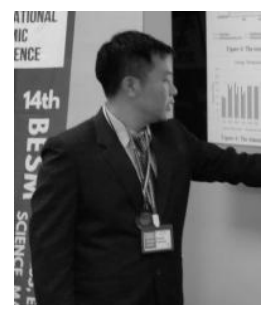

Tikhamporn Punluekdej

PhD, Lecturer in Graduate School, South-East Asia University, Bangkok, Thailand Science interests: national policy, legislative system, Governance, economy and social regulation

E-mail: tikhamporn.pu@gmail.com 


\section{TRANSFORMATIONAL LEADERSHIP AND EMPLOYEES'}

The task of administration in congruence with organization's policy and established goals always needs human resources as a key factor. The personnel are living organism with their own particular thoughts, emotions and capabilities that bring about development and changes into the organization. Capable personnel always lead to higher work efficiency and better quality of products together with the growth and prosperity of the company overall (Jaengmee, 2005: 2). Thus, the basic principle of human resource management is to delegate responsibility to employees so that they perform their tasks as specified in the company's objectives. Management, in its turn, should not only pay attention to employees' work but also to each and every single individual in the company. Management must find causes and ways for the personnel to carry on their work efficiently as specified in organizational policy and objectives.

In order to compete successfully in the highly competitive world, every firm must improve efficiency and effectiveness in every business-related activity such as production, finance and marketing. The cost of production must be kept at the lowest possible level while product quality must meet or go beyond the acceptable standards. The company must make sure that production supply is maintained at the continuous level in order to serve the needs of customers. In this regard, company's personnel are those whose roles and responsibilities become important factors for working harmoniously and running business successfully.

The leader who is professional, knowledgeable, and equipped with most appropriate leadership style, can persuade and, at the same time, motivate members of the company to work together at their highest capability and willingness becomes the most desirable factor of the company for its management (Kajornnun, 2008: 118).

Manning and Curtis (2015: 200) argued that no individual has been more influential than Peter Drucker in both research and practice of effective leadership. His books are classics on the subject, and his advice has helped six generations of leaders. In 1954, he wrote his famous text -- "The Practice of Management". Drucker's conclusions about leadership include: 1) There may be born leaders, but these are few. Effective leadership can be learned. 2) Without followers, there can be no leaders. Trust is the glue that binds the two. 3) Leadership is not rank, privilege, or title. Leadership is responsibility. and 4) Popularity is not leadership; nor is it style or personality. Leadership is results.

Performance management is at the heart of leadership success. It is important to have a vision; it is important to have values; it is important to have leadership qualities, such as vitality, persistence, and concern for others; it is important to have the power for leadership position. But all of these will result in little actual accomplishment without performance management skills. Effective leadership requires the art of clearly communicating goals, coaching others to succeed, and correcting poor performance (Ulrich et al., 1999; Pfeffer \& Sutton, 2006).

Nahavandi et al. (2015: 22) claimed that because of competition and increased access to information, business can succeed only if they are responsive to customers' needs. Managers must constantly evaluate how to respond well to consumers who demand better quality products and lower prices. The challenge to deliver quality at a lower cost has forced organizations around the world to seek ways to cut costs and become more efficient. Efficiency is defined as the most economical method to produce goods and services, using the least amount of resources. The need for quality and efficiency is a driving force in all industries because of consumer demands and global competition. These two factors are forcing businesses to find ways to do more with less. 
Every organization pays its employees for their hard work and efficiency. Individuals need to achieve the assigned targets within the desired time frame. It is essential for employees to meet deadlines and deliver results on time. Brenda Chitechi Okwang, Agnes Kinanu Mungania, and John Gakuu Karanja (2015: 119) in their research "Analysis of Factors Affecting the Operational Efficiency of Jua Kali Sector: A Case of Apparel Industry in Nairobi, Kenya" wrote that operational efficiency underpins companies' most basic strategic goals. Improving customer satisfaction and increasing shareholder value both depend on achieving operational efficiency. Therefore, improving operational efficiency is one of companies' top objectives. Companies indeed try to improve operational efficiency, but performance improvements fail because they are not properly communicated to all parts of organization. Most efficiency measures start at the top, yet employees' recommendations are necessary in the course of implementing strategic initiatives.

Based on the above discussion, the researcher is deeply interested in studying transformational leadership and work efficiency of employees at private companies in Bangkok metropolis in order to better understand the relationship between these two categories. The variety of leadership characteristics has its impact on work efficiency of employees and can lead to a positive change as well as to intensified development of employees' skills (Mathis, Jackson \& Valentine, 2013). The appropriate leadership style can be used as a model and motivation for employees to perform their work efficiently and completely in accordance with the policy and goals of their company.

\section{Objectives}

1. To study the level of transformational leadership and work efficiency of employees at a private organization in Bangkok metropolis.

2. To study the work efficiency in relation to individual factors.

3. To study the relationship between transformational leadership and employees' work efficiency.

\section{Literature review}

George and Jones (2006: 301) wrote that leadership is the process by which a person exerts influence over other people and inspires, motivates, and directs their activities to help achieve group or organizational goals. The person who exerts such influence is a leader. When leaders are effective, the influence they exert over others helps a group or organization achieve its performance goals. When leaders are ineffective, their influence does not contribute to, and often detracts from goal attainment.

Iqbal N., Anwar S. and Haider N. (2015) proposed that leadership is a process by which an executive can direct, guide and influence the behavior and work of others towards the accomplishment of specific goals in a given situation. Leadership is the ability of a manager to induce the subordinates work with confidence and zeal. Leadership can be defined as the capacity to influence group's achievement of a goal. Leaders are required to develop company's vision, and to motivate organizational members so that they themselves want to achieve this vision through improvement of their own performance. According to (Adair, 2002), leadership is the ability to persuade others to seek predefined objectives 


\section{TRANSFORMATIONAL LEADERSHIP AND EMPLOYEES'}

enthusiastically. It is the human factor which binds a group together and improve their performance directing them towards common goals.

Rosenfeld (2001: 46-48) explained that transformational leadership occurs when managers change (or transform) their subordinates in the following three important ways:

1. Transformational managers make subordinates aware of how important their jobs are for the organization and how necessary it is for them to perform those jobs as best they can so that the organization can attain its goals.

2. Transformational managers make their subordinates aware of the subordinates' own needs for personal growth, development, and accomplishment.

3. Transformational managers motivate their subordinates to work for the good of the organization as a whole, not just for their own personal gain or benefit.

According to Rosenfeld, when managers transform their subordinates in these three ways, subordinates trust the manager, become highly motivated, and help the organization achieve its goals.

Sarnrattana (2014: 27-28) argued that transformational leaders are those who are change-oriented. They encourage their followers to be aware of the opportunities and/or problems and to participate in creating company's vision pertaining to innovations in the company. Wirote described that transformational leaders use idealized influence to establish trust among workers, guarantee inspiration and motivation to provide challenging jobs and provoke teamwork spirit, intellectual stimulation to support creativity and problem-solving in a systematic way. Finally, individualized consideration could be provided by a leader through coaching and advising to each individual subordinate.

Schermerhorn (2005: 337-338) suggested that transformational leadership describes someone who is truly inspirational as a leader, who is personally excited about what they are doing, and who arouses others to seek extraordinary performance accomplishments. A transformational leader uses charisma and related qualities to raise aspirations and shift people and organizational systems into new high-performance patterns. Based on Schermerhorn's ideas, the presence of transformational leadership is reflected in the followers who are enthusiastic about the leader and his or her ideas, who work very hard to support them, who remain loyal and devoted, and who strive for superior performance accomplishments. In the context of continuous and often large-scale changes, additional inspirational impact of transformational leadership becomes essential.

Kouzes and Posner (1996) wrote that transformational leader provides a strong sense of vision and contagious enthusiasm that substantially raises the confidence, aspirations, and performance commitments of followers. Special qualities of transformational leaders include:

Vision - having ideas and a clear sense of direction; communicating them to others; developing excitement about the accomplishment of shared dreams.

Charisma - using the power of personal reference and emotion to arouse others' enthusiasm, faith, loyalty, pride, and trust in themselves.

Symbolism - identifying "heroes" and holding spontaneous and planned ceremonies to celebrate excellence and high achievements.

Empowerment — helping others develop by removing performance obstacles, sharing responsibilities, and delegating truly challenging work.

Intellectual stimulation - gaining the involvement of others by creating awareness of problems and stirring their imaginations. 
Integrity — being honest and credible, acting consistently out of personal conviction, and following through on commitments.

Peeraya Chuenwong (2017: 93-95) in her research titled "Operational Efficiency of Workers: A Case Study of Transportation Business in Chiang Rai Province" proposed that work efficiency is derived from performance and operational structure. Employees must come up with the operational concept and development in order to improve work efficiency. According to Sompit Sooksan (2556), the characteristics of work that is efficient are:

1. Agility -- refers to the best use of time in completing the assignments as well as the ability to finish work on time. Efficient workers always finish their work on time. In case of service, the speed is another important factor for customers. Therefore, service providers must create a culture that fits into a one-stop-service model.

2. Accuracy -- means there can be only a few mistakes in work, while the latter is highly relevant with rules and regulations, data, figures, or statistics. Accuracy also means there is no place for carelessness that can bring disaster to the firm.

3. Knowledge -- means the organization is well aware of what it does. Thus, it is considered a learning organization. People in such a learning organization are efficient and they are continuously looking for knowledge. They can do so by learning by themselves, learning from other organizations, and from the Internet, for example, and be able to use all the accumulated knowledge to improve their performance.

4. Experience -- means being knowledgeable. This may concern various perspectives that come from vision, touching and frequent practice of the same operations. In this context, knowledge and experience are least of all academic. And most of all it concerns accumulating work experience through time. It is undeniable that people with a lot of experience make fewer mistakes. Thus, it is a duty of every organization to keep the most highly experienced people since they can help the firm develop more rapidly.

5. Creativity -- means the ability to think of new things that can be used to benefit the organization, for instance, a new system that reduces the steps in providing services, a new method of work evaluation, and a proactive operation, to name just a few. An efficient person is the one who enjoys thinking, or is highly capable of thinking or always looks forward into the future; such personality doesn't like to follow orders and normally does not enjoy performing routine task. In response to robotic tasks such a person can often suggest a more creative solution and/or a brand new way how to perform the task.

\section{Methodology}

This study employs a quantitative research method. To collect the needed data, the questionnaires have been distributed to a target group of respondents.

\section{Population and Sample Size}

The population in this research consists of the employees working in a private organization in Bangkok metropolis, the total number being 104 persons. The key method in our research is simple random sampling. In order to get an appropriate sample size that represents the population, the researcher has used the formulated sample size table provided by Narong Srisawad (1999: 65). According to this source, the recommended sample size was 104 persons. Since the questionnaires have been hand-distributed by the researcher to these 104 respondents, the response rate has been $100 \%$. 


\section{TRANSFORMATIONAL LEADERSHIP AND EMPLOYEES'}

\section{Data Analysis}

The descriptive data include percentage, mean, and standard deviation.

\section{Results}

This table above shows that out of 104 employees, the majority have been male employees -- 58 persons, or 55.77\%. There have been also 46 female employees, or $44.23 \%$. Most of the employees (68 persons) have been 31-40 years old, this majority has formed $65.39 \%$ of the total sample; the second largest group in terms of age (26 employees) has been between 20-30 years old, this is $24.99 \%$. The rest -- 10 employees -- are $40+$ years old, this group represents $9.62 \%$.

Table 1. Individual Factors as Described by Percentage

(Source: made by the author)

\begin{tabular}{|c|c|c|c|}
\hline & Personal Factors & $\begin{array}{c}\text { Number (in } \\
\text { persons) }\end{array}$ & Percentage \\
\hline \multicolumn{4}{|l|}{ Gender } \\
\hline & Male & 58.00 & 55.77 \\
\hline & Female & 46.00 & 44.23 \\
\hline & Total & 104.00 & 100.00 \\
\hline \multicolumn{4}{|l|}{ Age } \\
\hline & $20-30$ years old & 26.00 & 24.99 \\
\hline & $31-40$ years old & 68.00 & 65.39 \\
\hline & $40+$ years old & 10.00 & 09.62 \\
\hline & Total & 104.00 & 100.00 \\
\hline \multicolumn{4}{|l|}{ Education } \\
\hline & Lower than Bachelor Degree & 16.00 & 15.38 \\
\hline & Bachelor Degree & 82.00 & 78.85 \\
\hline & Higher than Bachelor Degree & 06.00 & 05.77 \\
\hline & Total & 104.00 & 100.00 \\
\hline \multirow{6}{*}{$\begin{array}{l}\text { Work } \\
\text { Experience }\end{array}$} & & & \\
\hline & Less than 4 years & 12.00 & 11.54 \\
\hline & 4-6 years & 42.00 & 40.38 \\
\hline & $7-9$ years & 30.00 & 28.85 \\
\hline & More than 9 years & 20.00 & 19.23 \\
\hline & Total & 104.00 & 100.00 \\
\hline \multirow[t]{5}{*}{ Department } & & & \\
\hline & Marketing & 38.00 & 36.54 \\
\hline & Production & 40.00 & 38.46 \\
\hline & Finance & 26.00 & 25.00 \\
\hline & Total & 104.00 & 100.00 \\
\hline
\end{tabular}

The results also show that most of the employees are holding bachelor degrees -- the total number of 82 persons, or $78.85 \%$. Other 16 employees (or $15.38 \%$ ) have obtained lower 
than bachelor degree, and then also 6 persons (or 5.77\%) have got higher than bachelor degree education.

In terms of work experience, most of the employees (42 persons, or $40.38 \%$ ) have been working for the company in question for 4-6 years, 30 employees (or 28.85\%) have been with the company for 7-9 years, 20 employees (or equivalent to 19.23\%) have been with the company for over 9 years, and finally, 12 employees (or 11.54\%) have been with the company for less than 4 years. The results also reveal that 104 employees work mostly in the production department -- 40 persons or $38.46 \%$, then other 38 persons work in the marketing department, and then 26 employees work in the finance department.

Now let us turn to data analysis. The overall value of transformational leadership has been ranked quite high (mean $=3.67$ ). When each dimension considered separately, it has been found that the idealized influence factor is at the high level. It has been also found that intellectual stimulation and individualized consideration are at the moderate level. As for work efficiency, it has been found that the overall value of work efficiency is also quite high (mean $=3.79$ ).

When considered each item separately, it has been found that knowledge, accuracy, and agility factors are all at the high level. They are followed by experience and creativity factors. The results also demonstrate that the personal factor of gender does have any relationship with work efficiency at the statistical significance level of 0.05. At the same time, such individual factors as age, education level, work experience, and department affiliation have no relationship with operational efficiency.

Last but not least, the results demonstrate that there is a relationship between transformational leadership and work efficiency at the statistical significance level of 0.05 .

\section{Conclusions and Discussion}

Leadership styles have significant influence on operational efficiency, especially if we observe them in the contingency context. Although some authors (for example, Hall (1977), Brady and Helmich (1984), House and Singh (1987) and others) state that leadership styles in management do not have a decisive influence on work efficiency and corporate performance, such a standpoint - at least according to the data available to us - is not the standpoint of the majority. Although there is no uniform answer to the question which leadership style is the most efficient one, the research so far has shown that leadership style is the cause and not the consequence of company's performance, and that there are significant differences in leadership, monitoring, interpersonal relationships, application of methods, communication and other management components between successful and unsuccessful managers, that is, between organizational units which they are at the head.

Exploration of the relationship between leadership styles and performance and work efficiency starts from (Likert, 1967), who was the first to stress the importance of different leadership styles for performance and work efficiency, and who, basing on his empirical research, reached the conclusion that all leadership styles are the cause and not the consequence of work efficiency.

In this respect, the research conducted by Alka Agnihotri (2017), Iqbal N., Anwar S. and Haider N. (2015), Afsaneh Derakhshandeh and Reza Gholami (2012), Sombat Boonleaing, Saman Ngamsanit, Saard Bunjetrit, Khak Muldet, Patarapong Kroeksakul and Thongphon Promsaka (2010), Ali Mohammad Mosadegh Rad (2006), and Damir Skansi 


\section{TRANSFORMATIONAL LEADERSHIP AND EMPLOYEES'}

(2000) have found the relationship between leadership styles and organizational performance.

According to simple, early theoretical models, known as personality theories, "management efficiency depends primarily upon the personal characteristics of a leader". However, personality theories could not identify the personality characteristics which would guarantee managerial efficiency (Stodgill, 1974). The fact that contemporary research, like this one, has shown the existence of the relationships between personalities and managers' behavior on the one hand and managerial efficiency and corporate performance on the other, direct our attention further, towards some aspects of the personality theory (Yuk1, 1989). The question in which way manager's behavior influences efficiency was put forward. These theories have explored the behavior of certain managers and their influence upon followers and managerial efficiency. However, neither of these theories, among which the research by Likert, Blake and Mouton, and Fleshman are the most widely known, have identified managerial behaviors which would, under all circumstances, lead to efficiency (Damir Skansi, 2000: 52-53).

Transformational leadership occurs when managers have dramatic effects on their subordinates and on the organization as a whole, when they inspire and energize subordinates to solve problems and improve performance. These effects include making subordinates aware of the importance of their own jobs for the performance overall, making subordinates aware of their own needs in personal growth, development, and accomplishment, and motivating subordinates to work for the good of the whole organization and not just their own personal gain. George and Jones (2006: 326) concluded that managers can engage in transformational leadership by being charismatic leaders, by intellectually stimulating subordinates, and by engaging in developmental consideration. Transformational managers, as described by George and Jones, also often engage in transactional leadership by using their reward and coercive powers to encourage high performance.

One of the most imperative aims of company's management is to maximize the present and future financial and operational performance because they impact the market price per share and consequently, shareholders' wealth. Leadership styles and operational efficiency belong to the key determinants of long-term solvency for any business. In fact, firm-specific determinants of financial performance involve operational efficiency and financial risk. Leadership styles in relation to operational efficiency concept has become of concern due to increased competition, business processes and new technological evolution. Because of the intensity of changes in the business operation environment, firms face as never before serious competition and that is why good leadership styles and operational efficiency are critical for business success.

\section{References:}

Adair J. (2002). Effective Strategic Leadership. London: Macmillan Publishers Limited.

Agnihotri, A. (2017). Role of Trust Building in Leadership Efficiency. Journal of Advance Management Research, 5,5: 552-565.

Boonleaing, S., Ngamsanit, S., Bunjetrit, S., Muldet, K., Kroeksakul, P. \& Promsaka, T. (2010). The Leadership Characteristics and Efficiency of Local Administrative Organizations: A Case Study of Local Administrative Organizations in the Lower North Region of Thailand. International Business \& Economics Research Journal. 9 (12): 2-8.

Chitechi Okwang, B., Kinanu Mungania, A., \& Karanja, J. (2015). Analysis of Factors Affecting the 
Operational Efficiency of Jua Kali Sector: A Case of Apparel Industry in Nairobi, Kenya. European Journal of Business and Management, 7,30: 119-129.

Derakhshandeh, A. \& Gholami, R. (2012). Relationship Between Leadership Style and Perceived

Organizational Effectiveness by Directors and Managers in Organizations. Management Science Letter, 2: 845-850.

George, J. M. \& Jones, G. R. (2006). Contemporary Management: Creating Value in Organizations. New York, NY: The McGraw-Hill Companies, Inc.

Iqbal N., Anwar S., \& Haider N. (2015). Effect of Leadership Style on Employee Performance. Arabian Journal of Business and Management Review, 5:146.

Jaengmee, S. (2005). The Management to Create Work Satisfaction for the Employees at Matsushita Electric Works (Thailand) Co., Ltd. Master of Business Administration Degree Thesis. Phranakhon Si Ayuttaya Rajabhat University. Phranakhon Si Ayuttaya.

Kajornnun, N. (2008). Organizational Behavior. Bangkok. Se-Education Public Company Limited.

Kouzes, J. M. \& Posner, B. Z. (1996). Credibility: How Leaders Gain and Lose it; Why People Demand It? San Francisco: Jossey- Bass.

Likert, R.L. (1967). New Pattern of Management. New York: McGraw-Hill Book Company.

Manning, G. \& Curtis, K. (2015). The Art of Leadership. New York: McGraw-Hill Education.

Mathis, R. L., Jackson, J. H., \& Valentine, S. R. (2013). Human Resource Management. USA: SouthWestern College Publication.

Mosadegh Rad, A. M. (2006). Leadership in Health Services. 19,2.

Nahavandi, A., Denhardt, R. B., Denhardt, J. \& Aristigueta, M. P. (2015). Organizational Behavior. USA: Sage Publications.

Pfeffer, J. \& Sutton, R. I. (2006). Hard Fact, Dangerous Half-Truths, and Total Nonsense: Profiting from Evidence-Based Management. Boston: Harvard Business Publishing.

Rosenfeld, J. (2001). Lead Softly, but Carry a Big Baton. Fast Company, 48: 46-48.

Schermerhorn, Jr. \& John, R. (2005). Management. Danvers, MA: John Wiley \& Sons, Inc.

Skansi, D. (2000). Relation of Managerial Efficiency and Leadership Styles - Empirical Study in Hrvatska Elektroprivreda D.D. Management, 5 (2): 51-67.

Sooksan, S. (2013). Planning Technique and Evaluation. Paper Distributed in the Discussion of Planning Technique and Evaluation. Uttaradit: Uttaradit Rajabhat University.

Srisawad, N. (1999). Research Methodology for Sociology. Bangkok: Kasetsart University Printing. Stodgill, R.M. (1974). Handbook of Leadership: A Survey of the Literature. New York: Free Press.

Ulrich, D., Zenger, J. \& Smallwood, N. (1999). Results-Based Leadership. Boston: Harvard Business School Press.

Yukl, G. A. \& Wexley, D. (1985). Organizational Behavior. USA: Dow-Jones-Irwin.

Paper submitted

Paper accepted for publishing

Paper published online
14 May 2019

O3 July 2019

08 August 2019 